\title{
Forschungsbeiträge
}

\author{
Beate Collet \& Emmanuelle Santelli
}

Endogamy versus homogamy

\section{Marital choice among descendants of North African, Sahelian African and Turkish immigrants in France}

\author{
Endogamie versus Homogamie
}

Partnerwahl bei den Nachkommen von Immigranten aus Nordafrika, der Sahelzone und der Türkei in Frankreich

\begin{abstract}
Whom do French people of immigrant background choose as life partners? This question has raised new scientific interest in France because integration has been challenged by the endogamy norm. Using data from a 2007 study based on biographical interviews with 93 individuals, this article examines the balance between endogamy and homogamy, leading the authors to develop the concept of 'socio-ethnic homogamy' to account for the combination of cultural, social and gender dimensions that influence the choice of a conjugal partner among the descendants of immigrants. Their socialisation prior to marriage and their options for a conjugal partner at the time of union formation are being analysed empirically. The ways in which the norms of endogamy are reinterpreted by interviewees as well as the impact of cultural and social factors on the process of marital choice in the immigration society are being discussed in due course.
\end{abstract}

Key words: descendants of immigrants, marital choice, endogamy norm, socio-ethnic homogamy, cultural belonging, gender relations and social segregation.

\section{Zusammenfassung}

Wen wählen Franzosen mit Einwanderungshintergrund als Lebenspartner? Die Frage ist von neuem wissenschaftlichem Interesse in Frankreich, weil Integrationsfragen in Bezug auf Endogamieregeln neu hinterfragt werden können. Dieser Artikel basiert auf einer 2007 durchgeführten Studie, in deren Rahmen 93 biographische Interviews durchgeführt wurden, die es erlauben, die Wechselwirkung zwischen Endogamie und Homogamie zu untersuchen. Hierfür haben die Autorinnen das Konzept der sozio-ethnischen Homogamie entwickelt, um das Zusammenspiel von kulturellen, sozialen und geschlechtsspezifischen Dimensionen, die die Partnerwahl beeinflussen, zu erfassen. Die voreheliche Sozialisation der Befragten einerseits, und die Variationen der Wertvorstellungen zum Zeitpunkt der Paargründung andererseits wurden empirisch untersucht. Die Neuausrichtung der Endogamieregeln wird aufgezeigt und der Einfluss von kulturellen und sozialen Faktoren auf den Prozess der Partnerwahl in Einwanderungsgesellschaften wird diskutiert.

Schlüsselwörter: Nachkommen von Einwanderern, Partnerwahl, Endogamie-Norm, sozio-ethnische Homogamie, kulturelle Zugehörigkeit, Genderbeziehungen und soziale Segregation. 


\section{Introduction}

Immigration studies in France have diversified considerably in recent years. There is currently more research on post-migration and ethnic diversity, which no longer focuses exclusively on foreigners or immigrants themselves, but also consider their children, i.e. 'second generation', born or raised in the country where their parents had once settled. This paper deals specifically with marital choice among descendants of North African, Sahelian African and Turkish immigrants ${ }^{1}$ and seeks to understand how they reconcile their parents' cultural heritage with personal aspirations with regard to given marriage practices in France.

Studying the union formation among children of immigrants is interesting from two points of view. Firstly, only little research has thus far been conducted on different marital options of immigrant populations, whether they live in France or any other European country. Secondly, from a demographic perspective, a majority of immigrant children have reached the age of forming unions or marrying, therefore contributing to the creation of a new marriage market in their countries of immigration. ${ }^{2}$

Generally, studies conducted in France or other immigration countries have focused either on mixed unions, (Blau et al. 1982; Streiff-Fenart 1989; Meintel 2002; Kalmijn/ Turbergen 2006; Safi 2008) transnational marriages or marriage migration (Bailey/Boyle 2004a, 2004b; Kofman 2004; Waldis et al. 2006; Ballard 2008; Levitt 2009). Although the latter has drawn academic interest in France, no special research field regarding these matters existed here, contrary to the United States or other European countries, for example. (Shaw 2001; Beck/Beck-Gernsheim 2010; Kogan 2010; Charsley 2012).

Until the 1990s, researchers on North African immigrant families in France have looked into the marriage traditions inherited from a country of origin, especially on endogamy rules (Sad Saoud 1985; Zehraoui 1996). More recently, researchers have started to investigate the ways in which marriage practices of the children of immigrants have altered in relation to the values of the society in which they reside (Streiff-Fenart 2006; Collet/Santelli 2012a). Indeed, descendants of immigrants follow several patterns such as endogamy and exogamy. They happen to choose a partner of same origin as their parents (endogamy), whom they meet in the immigration country or in their parents' country of origin. Others get married with partners of French origin, who have no direct link with migration as well as with other immigrants and descendants of immigrants of all origins (exogamy). It is of great interest to us to examine all the existing marital patterns to understand which factors explain the different marital options of the second generation better. Migration to France is not a new phenomenon.

A majority of immigrants came from former French colonies in North and Sahelian Africa. As for labour migration from North Africa, it began in Algeria between the two world wars. In the 1960s and 1970s, migration has become a more diversified phenomenon, with Algerian immigrants followed by Moroccan, Tunisian and Sahelian African

1 The countries in question are for North Africa: Morocco, Algeria, and Tunisia; for Sahelian Africa: Senegal, Mauritania, Mali, and Guinea. Most African migrants in France come from these countries which are former French colonies.

2 See the summary proposed by Huschek/de Valk/Liefbroer (2012) in their study on Turkish second generation in seven European countries. 
ones. In general, migration for family purposes have consolidated the immigrants' settlement in France in the 1970s, this was less so the case for labour immigrants from Sahelian Africa who started to bring their families into this country later than North Africans. A significant number of Turkish immigrants began to arrive from the 1980s onwards. African and Turkish immigrants currently account for nearly half of the total immigrant population in France ${ }^{3}$ and their children are today at an age to marry and start families of their own. ${ }^{4}$ These ethnic communities are regarded with prejudice in France because of their reference to Islam and are socially marginalised: they may be affected by poverty, urban segregation and unemployment. In a highly secularised society as France, their sense of belonging and religious practices often lead to political debates and misconceptions, despite the fact that not all of the people identified as Moslems are highly involved in religious practice (e.g. going frequently to mosques). On the contrary, most of them consider religious belief as a private matter.

With regard to their social conditions, these immigrant populations, including their children, are more severely affected by unemployment than the non-immigrant populations (almost double the rate according to the National Institute of Statistics and Economical Studies - INSEE - in 2008). They are also usually the ones who live in the most deprived urban areas, their children experience discrimination and have high school dropout rates (Beauchemin et al. 2010). In France, the banlieues remain a critical issue, as have the riots of 2005 as well as the recent terrorist acts of 2015 demonstrated the scale of the problem.

This article brings into light the different possible marital options that immigrants' children hold, whose parents are either North African, Sahelian African and/or Turkish. Its specific aim is to understand those factors that influence a particular marital choice over another. It looks into the cultural, social and gender dimensions, which, in different combinations, reveal how individuals make a marital choice. Conjugal options are not solely a private matter; they are also revealing wider social relations as several authors have already shown for the American context since the 1980s (Peach 1980; Blau et al. 1982), and other authors in more recent years for France (Lagrange 2010; Lapeyronnie 2008). Cultural choices may also be the result of social pressure, for instance economic or residential living conditions or experiences of discrimination.

After the presentation of methods and data, the first section of the article will introduce 'socio-ethnic homogamy', a new theoretical concept that we propose and will guide our analysis. Socio-ethnic homogamy takes into consideration those social, ethnic, cultural,

3 According to the 2004 census, almost five million immigrants were living in France, 1.7 million came from one of the 25 European Union member states (with the largest numbers from Portugal, Spain, Italy, Germany, the UK and Poland), 1.5 million from one of the three countries of francophone North Africa, and 1.65 million from the rest of the world (including more than one-sixth from eastern Europe). The majority of immigrants from other countries were born in Asia (including 16 per cent for Turkey alone) and sub-Saharan Africa (of whom seven out of ten are from a former French colony; Borrel 2006).

4 The descendants of immigrants from the earlier migration waves (Italian, Spanish and Portuguese) are significantly older on the whole. Consequently, the union formation of young adults is not relevant for these migrants. On the other hand, descendants of immigrants from Asia and Eastern Europe are not old enough to be concerned of marriage. 
religious as well as individual factors affecting the changing marital choices of the children of immigrants. The following section will be more empirical and apply this concept throughout the results of this study. Our data, based on qualitative interviews, will provide distinct variations within socio-ethnic homogamy through three types of conjugal choice and lifestyle patterns; each illustrating a different relation between the endogamy norm inherited from parents and family and the more personal social life plans in French society. Conjugal practices are indicative of inter-generational changes at play in the second generation, and shed light on their mode of participation in modern, multi-cultural societies.

\section{Methods and data}

Our research pays special attention to the biographical method and specific sampling strategy. It is based on qualitative and biographical interviews conducted in 2007 . We consider that conjugal choice does not sum up to partners' matching social criterion, but is mostly the result of a life course before getting established as a couple. We believe that the process of forming a couple starts at an early age, the reason why our interviews take account of family socialisation, school and job career, as well as first love experiences and biographical events in different life spheres.

The fieldwork was carried out in the Paris and Lyon metropolitan areas by a team of interviewers who reached out to various social networks in order to obtain a diversified interviewee sample. ${ }^{5}$ The team distinguished between mixed and 'ghettoised' areas where they interviewed a total of 93 descendants of immigrants, 50 in the Parisian region and 43 in and around Lyon, who were all born or grew up in France. The interviewees consist of 58 women and 35 men, aged between 18 and 35. Their parents originate from the following three geographical zones: North Africa (59 persons), Turkey (14 persons), and Sahelian Africa (20 persons). The sample is made up by young adults who have started their partnership after 2002, having therefore less than five years of experience of conjugal life in 2007. 69 interviewees live together with their partner whereas 24 do not. Overall, 62 of them are married and 31 have one or two children. In terms of respondents' educational background, it ranges from vocational training to university degree. For example, 19 among them have attended university for four years or more. Despite their cultural differences, they have all been characterised by a reference to Islam and a patriarchal tradition for marital choices.

To stress more clearly on the orientation of mate selection, our protocol features various marital patterns. Children of North African, Sahelian African and Turkish immigrants:

5 E. Santelli/B. Collet (assisted by D. Boukacem and S. Ousmaal) (2007): Les choix conjugaux des descendants d'immigrés maghrébins, turcs et africains francophones, Direction des Populations et des Migrations. These results have been enhanced by another study: Collet/Santelli (2006): Les conjugalités mixtes des descendants d'immigrés en France et en Allemagne, Institut des sciences de l'Homme. A recent book provides a large overview on the results (Collet/Santelli 2012a). 
- forming couples with other children of immigrants, whose parents come from the same cultural and regional background (38 persons);

- forming couples with immigrants coming from the parents' country of origin, transnational endogamous marriages (31 persons);

- forming couples with French partners without any direct immigration background, born in France from two parents also born in France (17 persons);

- forming couples with French partners with a European immigration background (e.g. children of Portuguese or Spanish immigrants) or having one French and one foreign parent (7 persons).

The main aim in our sampling method has been to include diverse social profiles and conjugal patterns to be able to offer a more representative analysis. It is important to note, however, that the indicated number of interviews do not reflect their real distribution in French society. To overcome this gap, we have nonetheless accessed an extensive database through the survey Trajectoires et Origines (INED/INSEE 2008), carried out with 22000 individuals. On this basis, we can confirm that 22 per cent of North and Sahelian Africans and Turkish descendants of immigrants married an immigrant descendant raised in France; 39 per cent an immigrant; 24 per cent formed a couple with a French partner with no direct link to immigration, and 15 per cent with a French partner having an immigration background different from their own. ${ }^{6}$ The proportion of endogamous couples is higher when compared to the same proportion in earlier migration waves (i.e. Spanish, Italian, and Portuguese) and even compared to Asian descendants in France. It is interestingly lower, though, compared to the percentages of endogamous marriages among Pakistani in United Kingdom (Muttarak 2010) or Turkish immigration descendants in Germany (Kalter/Schroether 2010).

\section{From endogamy to socio-ethnic homogamy: A reinterpreted family norm}

The term endogamy is commonly used to refer to the marital choice of couples within the same group. According to Claude Lévi-Strauss, endogamy is an exchange of women through matrimonial strategies: inside the same genealogical or village group, it is called endogamy; outside the group, it is called exogamy (Lévi-Strauss 1971). Both endogamy and exogamy refer to specific social rules in societies where marriage is not an individual choice but a family arrangement, although it is rare today to see these rules in their original form, neither in the countries of origin nor in the countries of immigration. Endogamous marriages within the extended family is still practised in North and Sahelian Africa and Turkey, even if the marriage system therein has undergone considerable change, as Kamel Kateb (2000) has shown for Algeria, Ismet Koç (2008) for Turkey and Shireen J. Jejeebhoy as well as Zeba A. Sathar (2001) for India and Pakistan.

6 See a more statistical article of the authors analysing differences between mixed and endogamous couples of immigration descendants in France (Collet/Santelli 2012b). 
The reasons for this change can be explained by spatial mobility inside these countries, better education for women, access to international media and western references that loosened traditional marriage rules (Ouadah-Bedidi 2005). Henceforth, different marital practices coexist today: while some marriages are still consanguineous or familyarranged, others are the result of free will.

That said, in a post-migration context marital choices are relatively different and ethno-cultural belonging gains new relevance as it is about both preserving cultural identity and maintaining inter-generational transmission. Marriage keeps ethnic and family ties alive and facilitates entry into the immigration country by way of family unification. Parents or other family members who live in the country of origin are likely to exert social pressure in favour of a marriage with a partner from the same lineage group or coming from the same region. In this regard, families encourage transnational marriages between young people who did not grow up in the same social context. ${ }^{7}$ Yet, whereas some families still stick to traditional marriage rules, more and more couples are formed outside the lineage, even though their decisions are still guided by considering same ethno-cultural and religious belonging. Endogamy is thus a changing norm from the perspective of both parents and children. It turns out to be a condition set by family to marry someone who is considered to share a common culture. Nevertheless, it remains an elastic notion, depending also on social status and personal caracteristics.

Homogamy is usually studied by family sociologists to analyse mate selection in the majority group. It measures the match between the social characteristics of two spouses, regardless of their feelings of love. In fact, the term heterogamy is used when social characteristics of two spouses do not match. Family sociologists in France do not commonly use these terms for referring to an ethno-cultural identity or religion, ${ }^{8}$ unlike family sociologists in other European countries or the United States. ${ }^{9}$ Drawing on Kalmijn (1989), we use the concept of homogamy to insist on similarities of social status or educational level and we employ the concept of endogamy to examine same-group affiliations.

We will thusly consider the balance between endogamy and homogamy through our own findings in this article. This means that we will correlate respondents' shared ethnocultural references (such as religion, language, culture, sense of belonging to a minority) with their social life (job situation, educational level, lifestyle, family status, and migration experience). In order to do this, a new concept will be introduced, i.e. socio-ethnic homogamy, to deal with all the aforementioned dimensions simultaneously. It appears that in societies of post-migration, in-group considerations are intertwined with broader social status, and this is true for immigrants, their children and even natives. Based on empirical evidence, some parents and children place the lineage or cultural dimension above the social dimension, or vice versa, while others attempt to reconcile the two. When children of immigrants form an endogamous couple in line with the expectations of their parents, the

7 The central role of marriage alliances in migration processes, as well as the difficulties and risks they raise, have been studied for Indian and Pakistani populations in Anglo-Saxon countries (Gopalkrishanan/Babacan 2007; Charsley/Shaw 2006; Mohammad-Arif 2010) and for Turkish populations in France (Autant 2009), Belgium (Timmerman 2009) and Germany (Nauck 2002; Straßburger 2003).

8 For a summary of these discussions in France, see Bozon/Héran (2006) or Bozon/Héran (1989).

9 For a general overview concerning partner choice, see Hill/Kopp, in: Klein (2001). 
emphasis is on generational filiation that is experienced as an assertion of culture and identity while taking the social status into account. Conversely, respondents in an exogamous couple give priority to social status, shared interests or similar pathways. Overall, not only family socialisation matters in respondents' marital choice, but also the dominant Western values do, including self-fulfilment, romantic love, freedom of choice and gender equality. All of these influence their decisions. Besides, belonging to a minority or a distinctive religious community is kept alive through family values, and might be reinforced by experiences of discrimination. The choice of a marriage partner intrinsically blends these different registers of values and feelings. ${ }^{10}$

Considering endogamy and homogamy together makes it possible to capture the ways in which the sense of belonging and the elective rationale - which are constitutive of family ties in general (Déchaux 1998) - are reconfigured. From this perspective, the gender dimension is even more vital, because men and women have different rationales, as has been documented in the works of de Singly (1996) about middle class French couples; Wagner (2008) for aristocratic families, Timmerman (2006) for Turkish migration marriages and Zontini (2010) for Italian youth living in Italy and the UK. ${ }^{11}$

During their childhood years and as teenagers, the children of immigrants coming from North Africa, Sahelian Africa and Turkey have been in contact with other children having a different mind-set about marriage. They have had numerous opportunities to experiment love while also internalising parental endogamy values and different gender norms. Given this double reference system spanned over the years, how do they then choose between their parents' future plans for them and their own aspirations? The issue of marital choice is intrinsically linked with the environment in which one socialises. The area where one resides as well as school and occupation determine whom one meets in life. For any young adult, forming a couple is an assertion of his or her autonomy; this raises the question of reproduction or transformation of those values transmitted within the family circle. Our aim is to capture the rationale behind the action of immigrants' children in relation to their parents as well as to the same generation of young adults from the majority group.

\section{Variations of socio-ethnic homogamy: A typology}

This rich qualitative data gives us insight into many singular life stories. We have decided to analyse them by putting emphasis on the meaning interviewees attribute to their own marital choices with regard to the couple they formed at the moment of survey. Their decisions, embedded both culturally and socially, constitute the very variations of socioethnic homogamy and do challenge, for that matter, the endogamous norm. Three ideal

10 See the life course analysis which deals explicitly with pre-conjugal socialisation, i.e. family and residential socialisation, educational and occupational pathways and youthful love relationships (Santelli/Collet 2011).

11 Studies on migration phenomena or on the children of immigrants have gradually incorporated the concept of gender explicitly, because participation in family and community networks is not the same for men and women (Mahieu et al. 2010). 
types can be drawn according to Weber's tradition ${ }^{12}$ based on our empirical findings; ${ }^{13}$ each of which explains a different relation to the endogamy norm and to cultural and social aspirations of the children of immigrants in France.

The first type, inherited endogamy, corresponds to a model inherited from the parents' country of origin. Young people conform to their parents' wish without challenging it. A marriage along these lines is either arranged or imposed by parents; one's social status in the immigration country does not come into play. The second type, elective endog$a m y$, is present when young people conform to the expectations of their parents and family, culturally and socially, but choose their future spouse rather freely like other young people of their age do. For doing so, their achievements, in school and life in general, as well as common interests with whom they want to become partners, come across as important factors. The third type, denied endogamy, refers to a non-inclusion of inherited norms. It represents a highly individualised conjugal feature. Whether a person has a certain social status or other achievements to rely upon are not part of a conjugal project. For some, the non-respect of endogamy is endorsed by both the young people and their parents. For others, they go against the will of their parents. Whether that may occur overtly or subliminally, they break the chain of family transmission. Given the qualitative nature of this study, it does not make sense to quantify the results, rather analysing the material via the construction of a typology increases its value.

The most general outcome of our study confirms that there has been a shift from endogamy norms to socio-ethnic homogamy norms. Although descendants of immigrants do not allow themselves every imaginable marital choice, they do develop feelings for people with whom they anticipate a lasting relationship. Unlike in the generation of their parents, love becomes an essential criterion that guides the choice of a partner. In this respect, the behaviour of descendants of immigrants is comparable to other young people of their generation.

\subsection{Endogamy inherited from the country of origin}

In this first type, descendants of immigrants do not challenge the parental prerogative in marital choice. Marriage is not a personal affair, but a decision that consolidates family ties (Lievens 1999; Beck-Gernsheim 2007). Family members may arrange these marriages (Reniers 2001) - which often turn out to be transnational marriages and might bring together spouses belonging to the same family group. ${ }^{14}$

12 We used the analytical construct proposed by Max Weber. "An ideal type is formed by the onesided accentuation of one or more points of view and by the synthesis of a great many diffuse, discrete, more or less present and occasionally absent concrete individual phenomena, which are arranged according to those one-sidedly emphasized viewpoints into a unified analytical construct." (Max Weber, translated into English in 1997, p. 90).

13 The short format of an article does not allow to introduce all variations in interviewees' discourse, for more detailed description see our book (Collet/Santelli 2012a).

14 Doreen Huschek et al. (2012) found out that Turkish second generation couples, living in European countries and having a first-generation partner from Turkey, form more often consanguineous marriages than the ones living with second generation partners. 
This type of marriage formation reveals the existing asymmetry between men and women. Men may ask their mothers to find a wife for them in the country of origin. For these men, the ideal of a woman raised in the parents' country persists, and reflects their idea of a good wife, who will take care of household duties and childrearing (Timmerman 2009), among other things.

Sometimes men experience family pressure, to which they eventually relent. Just like their parents, they too are convinced that best marriages can be made within the same lineage group, and so they resign themselves to this belief. Below is the account of a young man, whose mother ferociously opposed that he might have a relationship with a young woman living in France, ultimately pushing him to agree to marry his cousin:

It was like a last chance I was giving her [my mother], and I did actually like the girl. I said to my mother, "Listen, we'll go back next year especially for her. If her parents agree, OK. If they don't, that's it. I won't do this anymore". (Man, 27 years old, Algerian origin, living in Paris region, secondary vocational education, salesman, married since 2003)

Despite the aforementioned, men seem to enjoy more freedom in opposing their parents' marital choices than women. Some decide to formalise an existing relationship with a non-immigrant French girlfriend when they sense that marriage negotiations are afoot within the family. Conversely, young women are more coerced to accept the suitors proposed by their parents. Whether they consent to these proposals or whether they yield to social and family pressure is hard to evaluate (Mathieu 1991), since family socialisation strongly prepares them for their marital fate. Women who fit in this type do not have a lot of freedom of speech and they are not used to discuss these issues with their parents. Besides, they also generally lack the means to do so; they have been involved in their family circle without much autonomy and tools for decision-making.

Survey results show that, compared to women in the other marital choice types, the women in arranged endogamous marriages have no or few educational qualifications. They have mostly grown up in an ethnic community, from which they have rarely been able to break away. More broadly, they have had few opportunities to leave the home environment, from where they draw emotional and material security. They have only a few relations outside the family circle.

Guler grew up in a small town near Lyon, in the much-deteriorated heart of city. She lived in a building with an inner courtyard, where most inhabitants were migrant families.

I grew up among other Turkish families, our next-door neighbour was my aunt [...] as children, we spent our days in the courtyard, always outside [...], in a shielded courtyard, banded together with other Turkish families [...] our parents were able to keep an eye on us from their windows. (Woman, 29 years old, Turkish origin, Baccalauréat, married to a man emigrated from Turkey)

If they see marriage and children as the natural cycle of life, they tend to agree that a marriage arranged within the family is a good idea.

My father told me about a cousin I had heard about in Senegal. I didn't refuse and I couldn't, because that's the way things are in my family. Your husband is chosen for you to avoid problems in the future. [...] I think it's a good thing. Most of the problems in couples occur because people are bound only by the bond of marriage. There is something more solid than that, that's family. Love comes later. What I mean is, that it [love] is not enough. You need something else, like family ties, respect, courtesy, dialogue, and matching personalities... (Woman, 25 years old, Senegalese origin, living in Paris region, junior secondary education, hairdresser in an African hairdressing salon) 
This management of marital choice represents a strict interpretation of endogamy. Other options, including marriage within the same ethno-cultural group in France, are ruled out, since the emphasis is placed on belonging to the narrowly defined community of origin. Marrying a member of one's extended family or someone originating from one's village reinforces the ties with the home country. The families in question live in France, but their relatives and investments in the country of origin remain a major preoccupation for them; many years spent in France do not suffice to change this country-oriented mind-set. In this regard, mothers seem to be unyielding in the sense that they believe their children's personal initiatives outside the traditional circle would destroy the fabric of their communities, whereas fathers seem to take family pressure into account to a higher degree.

Love is not a prerequisite for marital choice, but respect is. Men and women are conferred to different roles within the family. Social status is a matter of consideration, but it remains secondary when considering the preservation of lineage endogamy, perceived to be the sole guarantee for a 'successful' marriage. In extreme cases, this first type sheds light on the reality of so-called 'forced' marriages that stem from a mismatch between the expectations of parents and those of their children, particularly daughters (Santelli/Collet 2011).

\subsection{Elective endogamy}

Elective endogamy combines free will with loyalty towards family traditions and incur less social conflict (Nauck 2001). It involves choosing one's spouse freely, while respecting the expectations of parents that was internalised throughout childhood. In this case, when both women and men choose a marriage partner, they place as much value on social characteristics and mutual understanding as on cultural and religious similarity. Caught in a complex interplay between cultural identifications and their experiences in French society, they feel this choice is the most appropriate. This is not only due to family socialisation, but is also the logical consequence of social networks in the neighbourhood and at school. Thus, while respecting a mode of endogamy, young adults freely choose a spouse for whom they have feelings. The future spouse has to fit in their personal aspirations in terms of occupational status and family plans, but also be a caring person with whom they can easily communicate. By bridging the gap between endogamy and homogamy, their behaviour is similar to the younger generation of the majority society, i.e. choosing a spouse whom they love and feel close to socially, while conforming to the expectations of family.

The decision to marry is thus made by and within the couple, following a period of meeting each other during which the future spouses consolidate their feelings for one another. It is only later that they inform their parents and embark on formalising their relationship according to the conventions and traditional rites. Such a marriage, termed a 'halal marriage', combines feelings of love with cultural and moral duties while respecting the perceived order of things: dating, family consent, wedding, common household and ultimately shared intimacy (Collet/Santelli 2012a). 'Halal marriage', ${ }^{, 5}$ is a term ex-

15 Presumably, this term is coined to distinguish, as in other areas of everyday life, between the behaviours described in Islamic terms as 'pure' (halal) or 'impure' (haram). 
pressed by the descendants of North African origin in this study to refer to what they call a 'good marriage'. They specifically choose this term to define a legal union recognized by the community as such. However, this formula is specific to the society of immigration. In their parents' country of origin, it would not have been necessary to mention this because all marriage plans are, of course, seen as halal. From this, it follows that the main objective is to distance oneself from the dominant group and mark a difference between 'us' versus 'them'. Defining a marriage as halal means doing things differently than the French, e. g. premarital cohabitation and sex. From a feminist point of view, this is a way to keep young women's sexuality under control.

Here is the account of a young woman, who met her future husband at a very young age (at the age of 17 years). The couple took their time building on their relationship before marriage and waited until they had entered higher education for pursuing their job ideals.

As for background, I wasn't that specific. I just wanted a Muslim man who was interested in religion, because there are plenty of people who are Muslim by name only (...) he was mature, he was looking for a good person, he was a good person, too (...) we met each other all the time, he would pick me up after class (..) he even got a part-time job so he could buy me a little something when we met, or so we could go out to a café or the movies (...) when I told my father about him, I stressed on his family's criteria. (Woman, 23 years old, Algerian origin, living in Lyon, student enrolled in a Master's of Education, married to a man of Moroccan background studying accounting)

Some very pious, veiled women, actively involved in Islamic religious organisations do not respond to the expectations of their family. More generally, they adhere to the discourse within these organisations, which is a more rigorous interpretation of Islam. Their marital choice seems to reflect their reading of the Koran. Not only do they declare their wish to share certain religious precepts ${ }^{16}$ with their husbands, these women also report that they want to able to communicate and share mutual values, particularly with respect to raising children.

All in all, choosing a partner with similar cultural and religious traits is not solely a question of fulfilling the requirements of parental endogamy norms. Although peer-group control, especially in segregated suburbs, leads individuals to elect potential partners from within the same religious or ethno-cultural minority (Clair 2008), ${ }^{17}$ they do have an individualised relationship in mind.

Fatou and her husband didn't grow up in the same neighbourhood, but both lived in the same Parisian outer suburb:

It was the end of my professional training, we met at a party, we started to date from then on; his education is similar to ours, he was born here, practicing [Islam] and he is Fulani, like myself (...) we would meet every Friday after class (...). Our parents didn't know each other, but we both have some family over there [in the country of origin]. My family talked to his family and said that they were good people. (Women, 22 years old, parents coming from Mauritania, professional training)

Sometimes, the decision to conform to the parental norm is rooted in personal experience. It is possible that respondents have witnessed conflictual mixed marriages in their entou-

16 Such as accepting to meet a man only on condition that he has a serious intention of marriage.

17 See also Huschek et al. (2012). One of the results of the European TIES study is that having fewer non-coethnic contacts increases the likelihood of having Turkish second-generation partners. 
rage or marriages that were disapproved of by their families. Besides, discrimination particularly faced by young men contributes to their decision to marry someone from the same background. The idea is that the parents of a 'French' or 'European' girl might disapprove of their daughter's 'Turkish' or 'Arab' boyfriend. Young couples do not always withstand the test of racist hostility from their partners' parents.

There was only one girl I was serious about. She was studying pharmacy and her background was Spanish. Her parents were much undecided - one day it was yes, another it was only fine if it stayed a fling and didn't turn into anything else. She no longer wanted to go to her parents' home, but I didn't want her to cut off ties with them. Whatever happens, she can forget me, but she can't forget her parents. (Man, 28 years old, Moroccan origin, living in Paris region, secondary certificate in accountancy, now a porter, married to a French woman of Algerian background since 2005)

The fact that North African parents accept that their children form unions with children of immigrants from another North African country clearly shows a re-interpretation of endogamy. A reference to the same cultural region in the broad sense, North Africa, and to the same religion, Islam, is enough to obtain their consent. The same tolerance, however, is not shown to a Muslim spouse of Sahelian African or Turkish background. Similarly, a union with a non-immigrant French spouse who has converted to Islam will always be perceived as a mixed marriage, even if some families accept it as feasible.

Elective endogamy has the advantage to respond to a twofold expectation: a personal one forged through interaction with others, and a family expectation, based on intergenerational loyalty and a sense of belonging. Consequently, these couples see their choice as striking the perfect balance between the culture they inherited from their parents and their future in French society. Compared with union formation in the majority group, it appears that elective endogamy is the main mode for partner choice. For the children of immigrants, the cultural dimension of their choice is more visible on the grounds that they belong to a minority group, whereas for couples in the majority group, the cultural dimension is merely taken for granted.

\subsection{Denied endogamy}

Denied endogamy is practiced by those descendants of immigrants who disregard the family norm of endogamy for two reasons. Either they have not been socialised accordingly, or they bluntly deny family prescriptions. These couples are exogamous, i. e. from different cultural backgrounds. However, they do not have a homogamous strategy either. They believe that interpersonal understanding comes first. Thus, dating freely and falling in love with their partner presents a whole set of affinity choices beyond social conventions.

However, their choice may or may not be accepted by their parents. Some parents do not want to interfere by arranging a marriage for their children raised in France. One reason would be that they have had their hardships in life or seen their brothers or sisters experience unfortunate marriages. It is also the case of a mother who has been forced to 
raise her children on her own after a separation or death of her husband. ${ }^{18}$ Another raison would be that parents preferred to move away from the prescriptions of their community regarding marriage.

I noticed that in most of the arranged marriages around me, one of the spouses is often unhappy about this, as they rarely decide it themselves. Often they don't even know each other, that's why I am absolutely against it. Of course, I talked about these things with my parents, only to criticise, as for my parents it is an unfair practice, too. (Man, 26 years old, parents from Turkey, Bachelor's degree, engaged to a women coming from Turkey)

In these cases, young adults did not experience family disapproval when they announced their intention to marry or live with someone from outside their own ethno-cultural group. Generally, they simply informed their parents following a long lasting relationship with their partner.

Nevertheless, religious affiliation is still a crucial issue. Marriage with a non-Muslim is not seen in the same way for both sexes: what is tolerated for men might be rejected for women. ${ }^{19}$ This perception is strongly anchored in the collective representations of Muslim immigrant populations. ${ }^{20}$ Therefore, a Muslim woman might require her non-Muslim husband-to-be to convert to Islam, sometimes only for the sake of pretence to get her family's approval.

Taking studies based on other social groups into account, it seems that the unequal treatment of men and women with regard to marriage outside the group is not unique to our sample: an analysis of choice of marriage partner among the French aristocracy and upper middle class has shown that the requirements on women are so much more stringent that some women prefer to remain single (Wagner 2008). Because they integrate their wives into their own family circle, men have less difficulty imposing their choices, regardless of their wives' social status or culture.

I was the first to get engaged in my family. I had no model, so I did things my way. I told them I was getting married. For me, that was it. I only introduced my fiancée much later. I told my brothers and sisters, and later my mother. She was fairly positive, sounded quite positive... but after she talked to her friends and relatives, she was a bit reticent and later she told me she was against it. But I talked her round to it: there was no other way. (Man, 27 years old, Algerian origin, living in Paris region, youth worker married to a French woman of non-immigrant background, who converted to Islam in her late teens)

Parents who do not wish to influence their children's marriage decision are ultimately those who have accepted that their children's future is in France. They have faith in their children, who are exploring new marital territory. Based on our findings, these children are usually well-educated and have stable jobs.

Some children of immigrants coming from North Africa, Sahelian Africa or Turkey enter relationships, notwithstanding their parents' disapproval. After a period of hesitation, they decide to go against endogamous rules. They seem determined to keep up with personal

18 As fathers are often much older than their wives, the probability is high that they pass away during the childhood of their children. If parents are in conflict with inherited family values, as divorced mothers, they seem to abandon the endogamy norm.

19 For an interpretation of gender asymmetry in mixed marriages, see Collet (2012).

20 More modern interpretations of Islam no longer stress this. 
affinities and their plans for conjugal life. The disapproval of certain families might concern a French spouse of non-immigrant background or even a spouse from the same cultural region under the pretext that their child is bringing a stranger into the family (i.e. someone from outside the lineage and/or village). Such disapproval can be harsh on children, as the parents may refuse to attend the wedding or meet the spouse at all, and the conflict can last for years.

My parents came to our wedding - at the last minute - only because they didn't really have a choice. There was a sense of "What will people say?", so they came, but they left as soon as the ceremony was over. For a time, I was not on speaking terms with them, or with my sisters and some of my brothers because I'm the only one in the family who imposed my choice of spouse. In my family, no one dared to go against my mother's wishes. To this day, my parents have never really accepted my wife. (Man, 39 years old, Algerian origin, living in Paris, multimedia journalist, married to a woman of Moroccan background)

The attitude of parents can lead their children down to a path where they have a relationship secretly. In this case, parents usually do not know about the relationship in question, when sometimes sisters or brothers may know about it. It turns out such secretly-held relationships are tolerated for men so long as they are not formalised by a marriage. By contrast, when women hold their relationship hidden from their families, it is much more unlikely that they formalise it, thinking it would be an act against family honour. In fact, these secret relationships are possible only when women live away from their parents' home. They take advantage of this freedom to experience a marital relationship or intermittent cohabitation. Men and women who fit this type have a higher educational level than those of the two other categories. They have mixed social networks and share common interests with persons belonging to these networks (arts, music or sport).

Among those women having a secret and long lasting relationship, some will never officialise it. Oscillating between inherited and present-time values, they feel that their partner ultimately does not correspond to their ideal of marriage.

My boyfriend is not the ideal man for me. We have been together for a long time, but living separately has been very convenient for us. I am Turkish French, but he is French. We see things differently, we have different logics, the construction of our ideas is different. [...] I will marry only when I have found the one who will really suit me. For the moment, I have plenty of things to do. (Woman, 33 years old, parents coming from Turkey, Bachelor of Arts)

Denied endogamy illustrates the gap between parents' values and children's desire for a more individually-driven lifestyle. Parents have difficulty holding back their expectations and children do not see a way to find a common ground with their parents. Sometimes children break up with their family because of a painful experience, e. g. in the case of a violent father or sisters who have been forced into marriage. At times, they cannot resist the family refusal and therefore break up with their partner.

Ideal types highlight some crucial characteristics in behaviour, although we are aware that they also provide a rigid vision of society. Marital option might have been different in a former relationship or the other way around in a further one, but as a matter of fact, couples have to separate or divorce first. 


\section{Minority groups and social relations in France}

Our analyses through ideal types have revealed how socio-ethnic homogamy functions, affecting intergenerational and gender relations as well as ethnic affiliation. Ideal types allow room for comparison with the majority group as well.

Studying the balance between endogamy and homogamy, we come to realize that there is a shift within intergenerational relations. In the first type, parents and children agree on a more traditional concept of marriage formation, to which younger generations adhere out of respect for their parents, carrying in themselves a sense of communal identity. In the second type, children internalise cultural prescriptions and social conventions, but inspired as they are by subjective aspirations, they are also capable of free choice. In this case, parents seem alleviating some of their expectations, ultimately supporting their children's marital choice. In the third type, affinity dictates children's choice of a partner, whether or not their parents approve, which can lead to situations of disagreement or even conflict in which inter-generational communication breaks down.

However, the typology reveals asymmetric gender relations. The traditional gender divide places the heaviest burden on women in all cultures. ${ }^{21}$ Breaking with the endogamous norm is more difficult for women, who hence tend to accept the expectations of family and community. Men are given more leeway to circumvent these expectations. Family pressure can be subtle when young adults have internalised family expectations, but becomes virulent, or in some cases even violent, especially against women.

When we consider ethno-cultural belonging, the different groups are not equally involved in the aforementioned ideal types. Without stating exact percentages because of the qualitative approach, it seems that Turkish and Sahelian African descendants are all the more concerned by the first type, whereas North African descendants seem to be the group who lean towards elective endogamy type. Specific migration conditions and the marriage market in France undoubtedly play a role in this. The North African group is the most numerous in France; they are well-established, and their children have more opportunities to find partners with same cultural affiliation, whether that be at school, university, work or in the neighbourhood and even through community mate-matching websites.

The Sahelian and the Turkish groups are not numerous enough to have a differentiated marriage market inside France. Therefore, they seem to stick to more traditional marital choice patterns. The Sahelian group coming from several different countries and ethnic groups within their home setting, remains highly involved with ancestral marriage rules. For the Turkish group, the explanation is different. In France, Turks are a minority among minorities. They are Moslem but they do not share a common history with African immigrants with Moslem background. Whereas in Germany, having a significant marriage market, they prefer to marry with other Turkish descendants they easily meet up in daily life (Straßburger 2003; Huschek et al. 2012), the Turkish group in France resorts to transnational marriages. This shows that they have been able to transform traditional arranged marriages in their home villages and towns (Nauck 2002; Timmerman 2009).

Compared to young adults of the majority group, the children of immigrants coming from North Africa, Sahelian Africa and Turkey differ in their way to form a couple. Our

21 See the work of Héritier (1996) on 'differential valence of the sexes'. 
study shows that they do not live together outside marriage (except the third type), a behaviour that is by far the most common type of initial union formation in the majority group. In our sample, almost nine out of ten cohabiting couples are married. ${ }^{22}$ This reveals that descendants of immigrants with a Muslim background enter adult life differently. Marriage continues to play an important role and there seems to be no room for any other form of cohabitation. Marriage materializes when couples have achieved economic stability to establish themselves on their own. ${ }^{23}$

This specific transition to adulthood is even more pronounced for those young women of this group whose socialisation was centred around home, their dates were limited and sexuality under control (Phalet/Schönpflug 2001). Women from this group have fewer opportunities for experimenting love, leaving the parental home and living with a partner (outside marriage) than women of the majority group and even their male counterparts.

\section{Concluding remarks: Internal motivations and external pressures in marital choice}

Toward the end of this article, we want to stress again that the various options of marital choice show with evidence a reinterpreted endogamy norm. This is a consequence of cultural transitions as much as of social conditions of the different ethno-cultural groups in the immigration country.

Marital choice continues to be viewed in reference to an endogamous norm that refers back to a more or less sharply delineated original ethno-cultural group. The empirical study shows, however, that some couples, especially transnational ones, conform to the lineage norm, whereas couples consisting of two children of immigrant background have clearly reinterpreted the endogamy norm. On both sides of the inter-generational chain (from parents to children), endogamy is believed to ensure a lasting marriage. However, not everyone conforms to endogamy. When they deviate from the norm, they must justify their choice and the credibility of their union.

This typological analysis highlights an emerging form of marital choice, which has been unexplored until now. Elective endogamy emphasises ethno-cultural and social similarity based on common experiences, such as being children of immigrants, having lived in a social housing estate or experienced various hardships in society. It is centred on things that both partners in the couple feel that these should be shared. The parents' region or village of origin is less important than having immigrant parents who inculcated a substratum of common values. It is important for the spouse to have grown up in French society and correspond to aspirations in terms of social status and mutual understanding. In this sense, this is a homogamous rationale.

22 The results of various qualitative studies or targeted quantitative studies confirm this hypothesis of specific behaviour of children of immigrants. (e.g. TIES The Integration of the Second Generation French survey INED, 2007 and Trajectoires et Origines - INED/INSEE 2008), cf. Crul/Heering 2008.

23 The most economically vulnerable young adults are rarely in unions (Santelli 2007), which explains why they are also absent from this sample. 
Shared religion is a strong support for identity and an important aspect for mutual understanding and family projects, but we cannot separate it from ethno-cultural belonging. The religious argument is put forward by North African immigration descendants whose parents come from different countries in North Africa. Islam as a reference is perceived to be more important than ethnic origin. The other side of the coin, however, is that it turns out that religion fails to be inclusive for couples from different Moslem ethnic groups (e.g. couples formed by a North African descendant and a Turkish descendant, or a North African and a Sahelian African descendant). These couples experience disapproval from their parents and relatives.

However, ethnic and religious features must also be regarded in relation to economic and social conditions of their family, neighbourhood relations, school and professional careers. Different kinds of pressures burden them: the longer their school education lasts, the more they free themselves from family pressure; the more discrimination they experience, the more they seem to stick to their own cultural belonging. Especially in a context of social exclusion and residential segregation, elective endogamy takes the form of selfprotection and becomes a response to discrimination. The difficulty of perceiving the society in which they live as truly multicultural, their marital preferences are affected by repeated experiences of racism, rejection, and inequality. It is thus a sign of a twofold balance of power, both internal - an issue of identity, unremitting reaction to a minority status - and external - more disadvantaged social conditions for these young French people of immigrant parents, especially in terms of employment.

The analysis presented here has shown that the marital choice is a result of internal motivations and external pressures, with the majority society partly shaping the minority cultural rationales at play. In a back-and-forth identity positioning, the minority groups seek to differentiate themselves from the majority by maintaining or establishing specific cultural practices. It thus manifests their participation in the majority society and asserts a universe of values specific to them.

\section{References}

Autant, C. (2009). Saisir les identités en mouvement: parenté et histoires de familles turques en migration. Revue européenne des migrations internationales, 25, 3, pp. 133-151.

Bailey, A. J. \& Boyle, P. (Eds.) (2004a). Special issue: Family migration and the new Europe. Journal of Ethnic and Migration Studies, 30, 2, pp. 229-413.

Bailey, A. J. \& Boyle, P. (2004b). Untying and retying family migration in the New Europe. Journal of Ethnic and Migration Studies, 30, 2, pp. 229-242.

Ballard, R. (2008). Inside and outside: contrasting perspectives on the dynamics of kinship and marriage in contemporary South Asian transnational networks. In: Grillo, R. (Ed.), The family in question: Immigrant and ethnic minorities in multicultural Europe. Amsterdam University Press (IMISCOE Research), pp. 38-70.

Beauchemin, C., Hamel, C. \& Simon P. (Eds.) (2010). Trajectoires et Origines. Premiers résultats. Paris: INED-INSEE (Documents de Travail 168).

Beck-Gernsheim, E. (2007). Transnational lives, transnational marriages: A review of the evidence from migrant communities in Europe. Global Networks, 7, 3, pp. 271-288.

Beck, U. \& Beck-Gernsheim, E. (2010). Passage to hope: Marriage, migration, and the need for a cosmopolitan turn in family research. Journal of Family Theory and Review, 2, pp. 401-414. 
Blau, P. M., Blum, T. C. \& Schwartz, J. E. (1982). Heterogeneity and intermarriage, American Sociological Review, 47, pp. 45-62.

Borrel, C. (2006). Enquêtes annuelles de recensement 2004 et 2005. Près de 5 millions d'immigrés à la mi-2004, INSEE Première, 1098, pp.1-4.

Bozon, M. \& Héran, F. (2006). La Formation du Couple. Paris: La Découverte.

Bozon, M. \& Héran, F. (1989). Finding a spouse: A survey of how French couples meet. Population: English Selection, 1, pp. 91-122.

Charsley, K. (Ed.) (2012).Transnational marriage. New perspectives from Europe and beyond. New York \& Abingdon: Routledge.

Charsley, K. \& Shaw, A. (2006). South Asian transnational marriages in comparative perspective, Global Networks, 6, 4, pp. 331-344.

Clair, I. (2008). Les jeunes et l'amour dans les cités. Paris: Armand Colin.

Collet, B. (2012). Mixed couples in France. Statistical facts, definitions, and social reality. Papers (Rivista sociologica - Spain), 97, 1, pp. 61-77.

Collet, B. \& Santelli, E. (2012a). Couples d'ici, parents d'ailleurs. Parcours de descendants d'immigrés. Paris: Presses universitaires de France (collection Le lien social).

Collet, B. \& Santelli, E. (2012b). Les descendants d'immigrés en couple mixte au prisme de l'enquête. Trajectoires et Origines, Enfances familles et générations, $n^{\circ} 17$, pp. 75-97.

Crul, M. \& Heering L. (ed.) (2008). The position of the Turkish and Moroccan second generation in Amsterdam and Rotterdam. Amsterdam: Amsterdam University Press (IMISCOE Research), pp. 143159.

Déchaux, J. H. (1998). Dynamique de la famille: entre individualisme et appartenance. In: Galland, O. \& Lemel, Y. (Eds.), La Nouvelle Société Française. Trente Années de Mutations. Paris: A. Colin, pp. 60-89.

Gopalkrishnan, N. \& Babacan, H. (2007). Ties that bind: Marriage and partner choice in the Indian community in Australia in a transnational context, Identities, 14, 4, pp. 507-526.

Héritier, F. (1996). Masculin/Féminin. La Pensée de la Différence. Paris: Editions O. Jacob.

Hill, P. B. \& Kopp J. (2001). Strukturelle Zwänge, partnerschaftliche Anpassung oder Liebe - einige Überlegungen zur Entstehung enger affektiver Beziehungen. In: Klein T. (Ed.), Partnerwahl und Heiratsmuster: Sozialstrukturelle Voraussetzungen der Liebe. Wiesbaden: Springer Fachmedien, pp. 11-34.

Huschek, D., de Valk, H. A. G. \& Liefbroer A. C. (2012). Partner choice patterns among the descendants of Turkish immigrants in Europe. European Journal of Population, 28, 3, pp. 241-268.

Jejeebhoy, S. J. Sathar Z. A. (2001). Women's autonomy in India and Pakistan: The influence of religion and region. Population and Development Review, 27, 4, pp. 687-712.

Kalter F. \& Schroether J. (2010). Transnational marriage among former labour migrants in Germany. Zeitschrift für Familienforschung/Journal of Family Research, 22, 1, pp. 11-36.

Kateb, K. (2000). La Fin du Mariage Traditionnel en Algérie. Paris: Bouchène.

Kalmijn, M. (1998). Intermarriage and homogamy: Causes, patterns and trends. Annual Review Sociology, 24, pp. 395-421.

Kalmijn M. \& van Turbergen F. (2006). Ethnic intermarriage in the Netherlands: Confirmations and refutations of accepted insights. European Journal of Population, 22, 4, pp. 371-397.

Koç I. (2008). Prevalence and socioeconomic correlates of consanguineous marriages in Turkey. Journal of Biosocial Science, 40, 1, pp. 137-148.

Kofman E. (2004). Family-related migration: A critical review of European studies. Journal of Ethnic and Migration Studies, 30, 2, pp. 243-262.

Kogan, I. (2010). Introduction. In: Kogan, I. (Ed.). Introduction to the special issue on Minority ethnic groups' marriage patterns in Europe. Zeitschrift für Familienforschung/Journal of Family Research, 22, 1 , pp. 3-10.

Lagrange, H. (2010). Déni des cultures. Paris: Seuil.

Lapeyronnie, D. (2008). Ghetto urbain. Paris: Robert Laffont.

Lévi-Strauss, C. (1971 [1949]). Les Structures Elémentaires de la Parenté. Paris-La Haye: Mouton. 
Levitt, P. (2009). Routes and roots: Understanding the lives of the second generation transnationally. Journal of Ethnic and Migration Studies, 35, 7, pp. 1225-1242.

Lievens, J. (1999). Family-forming migration from Turkey and Morocco to Belgium: The demand for marriage partners from the countries of origin. International Migration Review, 33, 3, pp. 717-744.

Mahieu, R., Timmerman, C. \& Vanheule, D. (2010). La dimension de genre dans la politique belge et européenne d'asile et de migration. Bruxelles: Institut pour l'égalité des femmes et des hommes.

Mathieu, N.C. (1991). Quand céder n'est pas consentir. In: Mathieu, N. C. (Ed.) L'anatomie politique. Paris: Côté Femmes, pp. 17-41.

Meintel, D. (2002). Transmitting pluralism: Mixed unions in Montréal, Canadian Ethnic Studies/Études ethniques au Canada, 34, 3, pp. 90-120.

Mouhammad-Arif, A. (2010). Au-delà de l'endogamie et de la mixité: les mariages endogames mixtes chez les musulmans indo-pakistanais aux Etats-Unis, Diasporas. Histoire et sociétés, 15, pp. 68-82.

Muttarak, R. (2010). Explaining trends and patterns of immigrants' partner choice in Britain. Zeitschrift für Familienforschung/Journal of Family Research, 22, 1, pp. 37-64.

Nauck, B. (2001). Generationenbeziehungen und Heiratregimes - theoretische Überlegungen zur Struktur von Heiratsmärkten und Partnerwahlprozessen am Beispiel der Türkei und Deutschland. In: Klein, T. (Ed.), Partnerwahl und Heiratsmuster - Sozialstrukturelle Voraussetzungen der Liebe. Opladen: Leske \& Budrich, pp. 35-56.

Nauck, B. (2002). Families in Turkey. In: Nave-Herz, R. (Ed.), Family change and intergenerational relations in different cultures. Würzburg: Ergon Verlag, pp. 11-48.

Ouadah-Bedidi, Z. (2005). Liens de parenté entre conjoints en Algérie. In: Vimard, P. \& Vignikin, K. (Eds.), Familles au Nord, Familles au Sud. Louvain-la-Neuve: Bruylant-Academia, pp. 137-155.

Peach, C. (1980). Ethnic segregation and intermarriage. Annals of the Association of American Geographers, 70, 3, pp. 371-381.

Phalet, K., \& Schönpflug, U. (2001). Intergenerational transmission in Turkish immigrant families: Parental collectivism, achievement values and gender differences. Journal of Comparative Family Studies, 32, 4, pp. 186-201.

Reniers, G. (2001). The post-migration survival of traditional marriage patterns: Consanguineous marriages among Turks and Moroccans in Belgium. Journal of Comparative Family Studies, 32, 1, pp. 21-45.

Sad Saoud, H. (1985). Le choix du conjoint: tradition et changement. Revue Européenne des Migrations Internationales, 1, 2, pp. 118-130.

Safi, M. (2008). Intermarriage and assimilation: Disparities in levels of exogamy among immigrants in France, Population, 63, 2, pp. 267-298.

Santelli, E. (2007). Grandir en Banlieue. Paris: CIEMI (collection 'Planète Migrations').

Santelli, E. \& Collet, B. (2011). De l'endogamie à l'homogamie socio-ethnique. Réinterprétations normatives et réalités conjugales des descendants d'immigrés maghrébins, turcs et africains subsahariens, Sociologie et Société, 43, 2, pp. 329-354.

Santelli, E. \& Collet, B. (2011). Forced marriages: Between social construction and experience of family enforcement. In: Thiara, R. K., Condon S. A. \& Schröttle, M. (Eds.), Violence against women and ethnicity: Commonalities and differences across Europe. Opladen \& Farmington Hills, MI: Barbara Budrich Publishers, pp. 241-255.

Shaw, A. (2001). Kinship, cultural preference and immigration: consanguineous mar-riage among British Pakistanis, Journal of the Royal Anthropological Institute, 7 2, pp. 315-334.

Singly de, F. (1987 [1996]). Modern marriage and Its cost to women. Newark: University of Delaware Press.

Straßburger, G. (2003). Heiratsverhalten und Partnerwahl im Einwanderungskontext. Würzburg: Ergon Verlag.

Streiff-Fenart, J. (1989). Les couples franco-maghrébins en France. Paris: L’Harmattan.

Streiff-Fenart, J. (2006) À propos des valeurs en situation d'immigration: questions de recherche et bilan des travaux, Revue française de sociologie, 47, 4, pp. 851-875. 
Timmerman, C. (2006). Gender dynamics in the context of Turkish marriage migration: The case of Belgium", Journal of Turkish Studies, 7, 1, pp. 125-143.

Timmerman, C. et al. (2009). Marriage at the Intersection between tradition and globalization. Turkish marriage migration between Emirdag and Belgium from 1989 to present. The History of the Family, 14 , pp. 232-244.

Wagner, A. C. (2008). Mariages assortis et logiques de l'entre-soi dans l'aristocratie et dans la haute bourgeoisie. Migrations-Société, 20, 119, pp. 229-242.

Waldis, B. \& Byron, R. (Eds.) (2006). Migration and marriage. Heterogamy and homogamy in a changing world. Berlin \& Zürich: Lit Verlag.

Weber M. (1997) [1904/1949]. The methodology of the social sciences, New York: Free Press (Edited and translated by E. A. Shils and H. A. Finch).

Zehraoui, A. (1996). Les processus différentiels d'intégration au sein des familles d'origine algérienne en France. Revue française de sociologie, 36, 2, pp. 237-261.

Zontini, E. (2010). Enabling and constraining aspects of social capital in migrant families: Ethnicity, gender and generation. Ethnic and Racial Studies, 33, 5, pp. 816-831.

Submitted on/Eingereicht am: 25. 09. 2014

Accepted on/Angenommen am: 25. 04. 2016

Addresses of the authors/Anschriften der Autorinnen:

Dr. Beate Collet (Corresponding author/Korrespondenzautorin)

Maîtresse de conférences (associate professor)

Université Paris-Sorbonne

Maison de la Recherche

28, rue Serpente

75006 Paris

France/Frankreich

Email/E-Mail: Beate.Collet@paris-sorbonne.fr

Dr. hab. Emmanuelle Santelli

Directrice de recherches CNRS (research director)

Member of the research unit Centre Max Weber

Université de Lyon

Institut des Sciences de l'Homme

14, avenue Berthelot

69363 Lyon Cedex 07

France/Frankreich

Email/E-Mail: Emmanuelle.Santelli@ish-lyon.cnrs.fr 